\section{DRASSROOTS}

ISSN 2581-6853
Grassroots Journal of Natural Resources, Vol. 4 No. 2 (June 2021)

ISSN 2581-6853 | CODEN: GJNRA9 | Published by The Grassroots Institute

Website: http://grassrootsjournals.org/ginr | Main Indexing: Web of Science

\title{
Agroecological Determinants of Potato Spatiotemporal Yield Variation at the Landscape Level in the Central and Northern Ukraine
}

\author{
Anastasiia Zymaroieva*1, Tetiana Fedoniuk ${ }^{2}$, Svitlana Matkovska ${ }^{3}$, Olena Andreieva ${ }^{4}$, Victor Pazych $^{5}$ \\ ${ }^{1}$ Department of Forestry and Ecology, Polissia National University, Zhytomyr, Ukraine. \\ Email: nastya.zymaroeva@gmail.com \\ ${ }^{2}$ Department of Forestry and Ecology, Polissia National University, Zhytomyr, Ukraine. \\ Email: tanyavasiluk2015@gmail.com \\ ${ }^{3}$ Department of Forestry and Ecology, Polissia National University, Zhytomyr, Ukraine. Email: matkovcka@ukr.net \\ ${ }^{4}$ Department of Forestry and Ecology, Polissia National University, Zhytomyr, Ukraine. \\ Email: andreeva-lena15@ukr.net \\ ${ }^{5}$ Department of Forestry and Ecology, Polissia National University, Zhytomyr, Ukraine. Email: forest.znau@ukr.net \\ *Corresponding author | ORCID: 0000-0001-9382-8269
}

How to cite this paper: Zymaroieva, A. Fedoniuk, T., Matkovska, S., Andreieva, O. and Pazych, V. (2021). Agroecological Determinants of Potato Spatiotemporal Yield Variation at the Landscape Level in the Central and Northern Ukraine. Grassroots Journal of Natural Resources, 4(2): 34-47. Doi: https://doi.org/10.33002/nr2581.6853.040203

Received: 08 April 2021

Reviewed: 21 April 2021

Provisionally Accepted: 30 April 2021

Revised: 05 May 2021

Finally Accepted: 10 May 2021

Published: 05 June 2021

Copyright $($ C) 2021 by author(s)

This work is licensed under the Creative Commons Attribution International License (CC BY 4.0).

http://creativecommons.org/licenses/by/4.0/

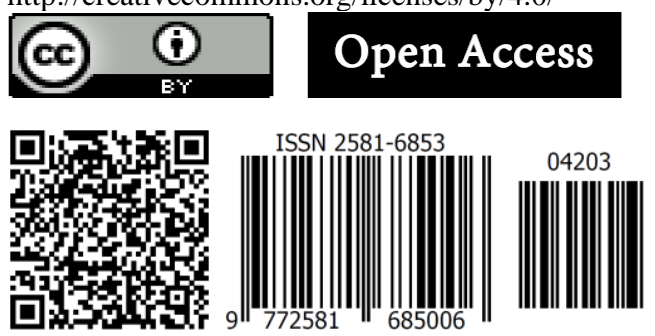

\begin{abstract}
Global food security largely depends on the crop yield increase, so the study of the yield-limiting factors of potato (the second bread) is a pressing issue today. This study determines the contribution of the agroecological factors, namely, bioclimatic variables, soil indicators, and factors of landscape diversity, to the variation in potato yields. Conducted in Polissya and Forest-steppe zones of Ukraine during 1991-2017, this study has not only addressed the relationship between ecological determinants and potato yields, but also considered crop yields as a dynamic system. The dynamics of potato yields from the mid-1990s to the present is described by a log-logistic model. There are statistically significant regression dependencies between potato yield parameters and agroecological factors. Potato yield is dependent on the diversity of landscape cover. The relationship between yield parameters and landscapeecological diversity is non-linear, which determines the presence of optimal landscape structure for the highest potato yields. Among climatic factors, the continental climate is of the greatest importance for potato yield. The high sensitivity of potato yield parameters to soil indices was found, and mostly the soil texture components (silt content), which largely determines the potato yield spatial variation.

Keywords

Yield; Ecological factors; Spatiotemporal variation; Potato
\end{abstract}


Grassroots Journal of Natural Resources, Vol.4, No.2 (June 2021), pp.34-47 | ISSN 2581-6853 | CODEN GJNRA9

Doi: https://doi.org/10.33002/nr2581.6853.040203

OPEN $\partial$ ACCESS Freely available online

\section{Introduction}

Potato production is the fourth largest in the world and the largest among non-grain crops since it is 'the second bread' in many countries, including Ukraine (FAO, 2019, Jennings et al., 2020). Potatoes have been cultivated in Ukraine since the 18th century, but the crop was adapted slowly to the Ukrainian climate until the end of the 19th century (Hamkalo, 2005). Although Ukraine is one of the world's top five potato producers in terms of gross production, the average yield per hectare is lower than in developed countries (FAO, 2019). This can be explained by the influence of economic and agrotechnological factors (Zymaroieva et al., 2020; Zymaroieva and Zhukov, 2020). Nevertheless, there are ecological drivers of potato yield dynamics (Haverkort and Struik, 2015; Stol et al., 1991), but their contribution to long-term variation of potato yield within the country needs clarification.

The most influential environmental factors determining crop yields are climate and soil properties (Schmidhuber and Tubiello, 2007; Ray et al., 2015; Feller et al., 2012; Lal, 2020). Climate drivers affect crop yields on the physiological level by regulation of the transpiration, photosynthesis, and respiration processes. The interaction of the meteorological factors with the crop responses is rather complex (Pereira et al., 2008).

In the experiments conducted on potato, it was shown that environmental factors such as rainfall (soil moisture) and temperature have a significant effect on its growth and yield (Diacono et al., 2012). Fluctuations in potato yield are determined both by the influence of weather conditions on the photosynthetic productivity of plants, and the influence of the same conditions on the spread of infectious diseases and pest outbreaks (Quiroz et al., 2018; Lakshman et al., 2020). According to the study of Zhao et al. (2016), the key climatic factors limiting potato yields in northern China over the past 30 years at a regional scale were diurnal temperature range, precipitation, radiation, and evapotranspiration. Moreover, the effects of climate change on potato yield are regionally diverse (Haverkort and Struik, 2015), this determines the relevance of present research.

There is a strong correlation between potato yield and soil nutrient factors (Wang et al., 2019). The soil structure, which defines water relations in agricultural systems, is also an important driver of potato yield variation (Redulla et al., 2002). Although, the impact of soil indicators on crop yields is a well-studied issue, yet the spatial aspect of yield variation depending on soil properties needs to be investigated. There is strong evidence of a sustained impact of biodiversity on crop yields both in the natural ecosystems (Hooper et al., 2005) and in agroecosystems (Picasso et al., 2008). Land-use diversity has an important role in ensuring higher yields and, as a result, resilient agricultural returns (Abson et al., 2013). However, the relationship between crop yields and biodiversity at the landscape level is insufficiently explored.

The aim of this study is to establish the contribution of the agroecological factors, namely, bioclimatic variables, soil indicators and factors of landscape diversity in the variation of potato yield in the central and northern Ukraine during 1991-2017.

\section{Methodology}

\section{Yield data and study area}

Potato yield data were obtained from the State Statistics Service of Ukraine ${ }^{1}$. The time series datasets include averages of the crop annual yields in 206 administrative districts of 10 regions of Ukraine during the period 1991-2017. The data represent the mean values of the yields based on the spatial criterion without differentiating soil water availability and fertility, irrigation management, cultivar, and crop cycle. The research area is located in two environmental zones: the Central European Mixed Forests ecoregion

\footnotetext{
${ }^{1}$ http://www.ukrstat.gov.ua/ 
(Polissia) and East European Forest Steppe ecoregion (Forest-steppe zone). Twenty-seven years' data series of the potato yields were available for 10 administrative regions (Cherkasy, Chernihiv, Khmel'nyts'kyy, Kyiv, L'viv, Rivne, Ternopil', Vinnytsya, Volyn andZhytomyr) (Figure 1) (Zymaroieva et al., 2020).

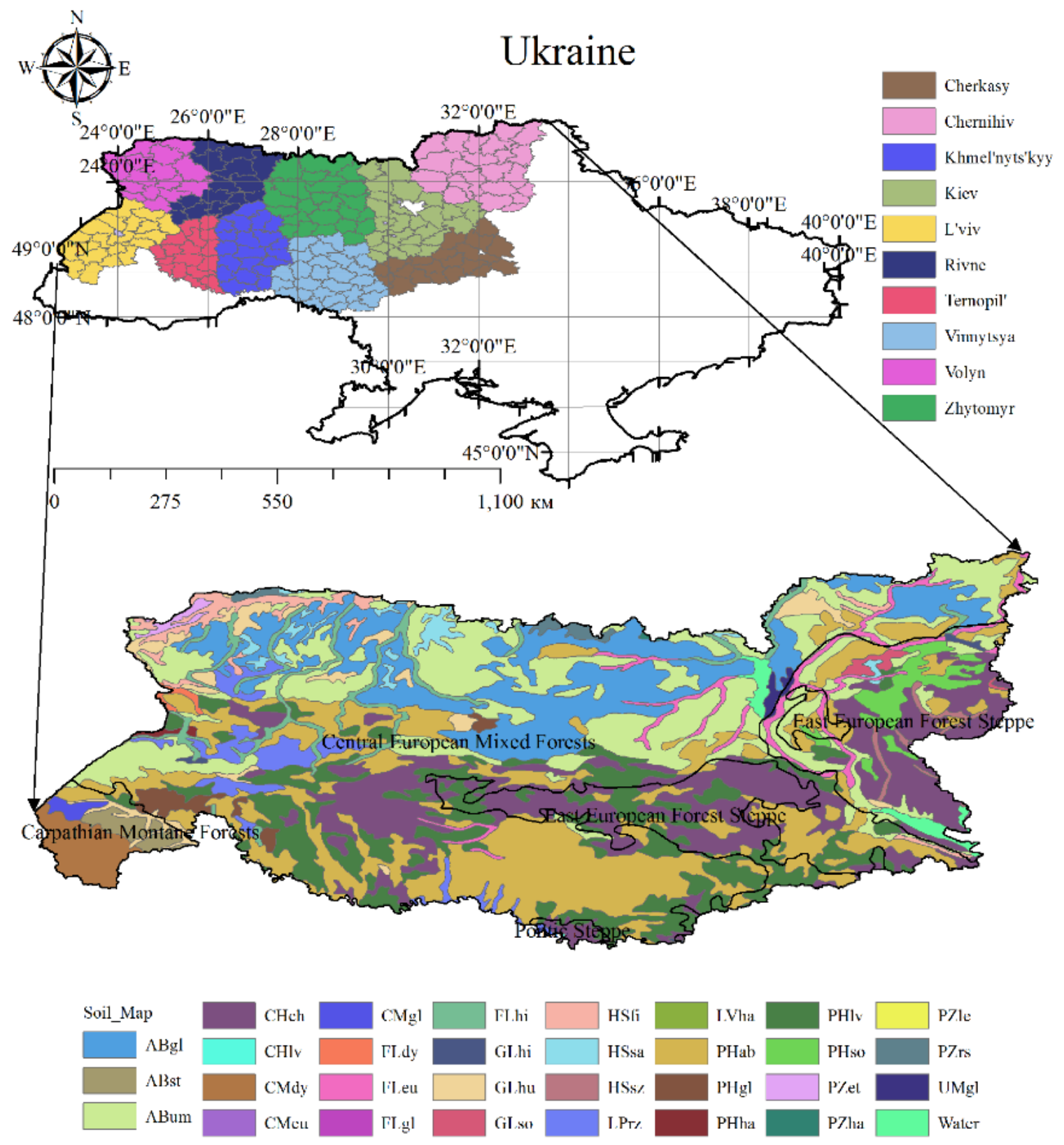

Figure 1: Map of 10 administrative region in Ukraine, Ecoregions and soil map.

Legends: Soil classification according World Reference Base for Soil Resources: ABgl -Albeluvisols Gleyic; ABst - Albeluvisols Stagnic; ABum -Albeluvisols Umbric; CHch -Chernozems Chernic; CHlv Chernozems Luvic; CMdy - Cambisols Dystric; CMeu -Cambisols Eutric; CMgl-Cambisols Gleyic; FLdy - Fluvisols Dystric; FLeu - Fluvisols Eutric; FLgl - Gleyic Fluvisols; FLhi - Fluvisols Histic; GLhi Gleysols Histic; GLhu - Gleysols Humic; GLso - Gleysols Sodic; HSfi - Histosols Fibric; HSsa - Histosols Sapric; HSsz - Histosols Salic; LPrz - Leptosols Rendzic; LVha - Haplic Luvisols; PHab - Phaeozems Albic; PHgl - Phaeozems Gleyic; PHha - Phaeozems Haplic; PHlv - Phaeozems Luvic; PHso - Phaeozems Sodic; PZet - Podzols Entic; PZha - Podzols Haplic; PZle - Leptic Podzols; PZrs - Podzols Rustic 


\section{Yield dynamics model and its characteristic points}

In this work, not just the relationship between ecological determinants and yield is studied, but crop yields are also considered as a dynamic system, which is characterized by changes in time and space. The choice of the model is explained by its statistical reliability and significant explanatory ability, which allows meaningful interpretation of crop yield data. The symmetrical four-parameter log-logistic model was used to describe the potato yield dynamics:

$$
Y=c+\frac{d-c}{1+\exp (b(\log (x)+\log (E D 50)))},
$$

where $\mathrm{x}$ represents years $(1-1991,2-1992, \ldots)$; $\mathrm{y}$ is the response (crop yield); $\mathrm{c}$ shows the lower response limit (the lowest yield level); $d$ is the upper limit (the plateau level of yields) when $x$ approaches infinity; $b$ is a slope of the response curve near the inflection point when $\mathrm{x}$ acquires ED50 (the time it takes to reach a half increase between the lower and upper limits). Hence, the log-logistic model has characteristic points that can be used as parameters of the variation of the yield (Figure 2): Lower limit indicates the lowest level of yields during the study period; slope - a slope of the trend curve, which shows the rate of yield change over time; ED50 - the time that is required to achieve half of the maximum yield level and at the same time the point with the highest rate of yield growth; upper limit - the highest level of productivity which, at the present level of agricultural technology development, is determined precisely by the biotic potential of the territory.

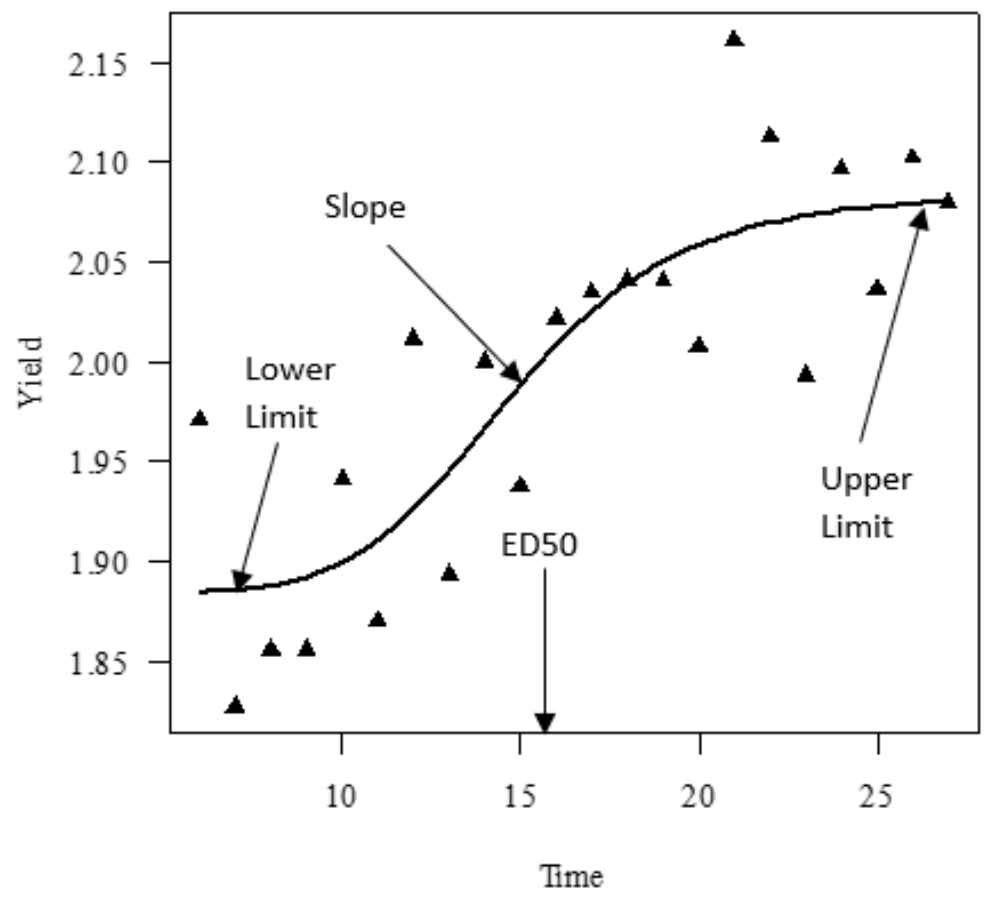

Figure 2: Typical dynamics of the potato yields during 1991-2017 and its approximation by the logistic model. The abscissa axis - years $(1-1991,2-1992, \ldots, 2017)$, the ordinate axis is the potato yield, $\mathrm{dt} \mathrm{ha}^{-1}$.

These characteristics of the potato yield dynamics were calculated for each administrative district and used as an integral quantitative indicator of the crop yield variation at a given point in space over a certain period of time (Kunah et al., 2018; Zhukov et al., 2018). The symmetrical four-parameter log-logistic model was used calculated by means of the $d r m$ function from the $d r c$ package (Ritz et al., 2015) for a language and environment for statistical computing $R$ (R Core Team, 2020). 
Grassroots Journal of Natural Resources, Vol.4, No.2 (June 2021), pp.34-47 | ISSN 2581-6853 | CODEN GJNRA9

Doi: https://doi.org/10.33002/nr2581.6853.040203

OPEN OA ACCESS Freely available online

\section{Climatic and soil characteristics}

Bioclimatic data were applied according to the WorldClim version 2 database ${ }^{2}$ (Fick and Hijmans, 2017). Climatic information is presented in the form of raster maps with a resolution of $1 \mathrm{~km}$, which is sufficient for the study purpose. The bioclimatic variables represent ecologically significant aspects of annual temperature and precipitation changes. 19 bioclimatic variables were used for analysis (Zymaroieva et al., 2021). The Box-Cox transformation to convert abnormal dependent variables to normal form was used (Osman et al., 2014), which was implemented using the AID library for the statistical computing environment R (R Core Team, 2020).

The principal components analysis was used to reduce the dimensionality of climate matrices and soil properties. General linear models were used to test the significance of the influence of climate and soil variables on yield parameters. The principal components analysis of climate variables allowed to identify four main components, the eigenvalues of which are greater than one and which together explain $92.5 \%$ of the variability of climate variables (Zymaroieva et al., 2021). Spatial variation of soil properties and soil classification were obtained from the SoilGrids database ${ }^{3}$ (Hengl et al., 2017; Zhukov et al., 2017). To analyze the impact of soil factors on potato yields, the indicators such as soil organic carbon (SOC), $\mathrm{pH}$, bulk density, sand, clay or silt content for different soil layers were used. As a result of the principal components analysis of soil variables, 6 principal components were identified with eigenvalues higher than one and which together explain 98.5\% of the total variance of soil indicators (Zymaroieva et al., 2021). Statistical analysis was performed using Statistica 10 software.

\section{Landscape diversity indices}

The $300 \mathrm{~m}$ GlobCover Landscape Type Map, based on the two-month MEdium Resolution Imaging Spectrometer (MERIS) (Ottlé et al., 2013; Fritz et al., 2015; Tsendbazar et al., 2015; Pérez-Hoyos et al., 2017), was used as a basis for creating a landscape diversity map. The landscape diversity was evaluated using the Shannon diversity index (Dušek and Popelková, 2017; Kunah et al., 2018; Zhukov et al., 2015). The diversity index was calculated for each focal pixel and the eight adjacent ones. Calculations were made using the Corridor Designer toolbox works in ArcGIS 10.1 (Majka et al., 2007).

Along with landscape diversity, the distance between objects is important (McGarigal et al., 2002; McGarigal et al., 2012; Koshelev et al., 2020). Natural protected areas (NPA) affect the productivity of the surrounding landscapes. Therefore, the distance to NPA was considered as a measure that reflects this influence (Chape et al., 2005; Fedonyuk et al., 2020). The distance between natural protected areas (NPA) and each pixel of the studied area was calculated. The average value of this index within administrative areas was used as a marker of the naturalness of the territory. Data about natural protected areas was obtained from https://opengeo.intetics.com.ua/osm/pa/ in the form of a shape-file. The distance was calculated using ArcGIS 10.1.

\section{Results and discussion}

Statistically significant regression dependences $(\mathrm{p}<0.05)$ between agroecological predictors and potato yield parameters in the studied region of Ukraine were established (Table 1).

Table 1: Regression dependence of potato yield parameters on climatic and soil variables, as well as indicators of landscape diversity*

\begin{tabular}{lcccc}
\hline \multirow{2}{*}{ Predictors } & Slope. & Lower Limit. & Upper Limit. & ED50. \\
& $R_{a d j}{ }^{2}=0.26$ & $R_{a d j}{ }^{2}=0.57$ & $R_{a d j}{ }^{2}=0.54$ & $R_{a d j}{ }^{2}=0.32$ \\
\hline Shannon $(\mathrm{H})$ & - & $-0.79 \pm 0.27$ & $-1.20 \pm 0.28$ & $1.18 \pm 0.34$ \\
\hline
\end{tabular}

${ }^{2} \mathrm{http}: / /$ worldclim.org/version2

${ }^{3}$ https://soilgrids.org 


\begin{tabular}{lcccc}
\hline Predictors & $\begin{array}{c}\text { Slope. } \\
R_{a d j}{ }^{2}=0.26\end{array}$ & $\begin{array}{c}\text { Lower Limit. } \\
R_{\text {adj }}{ }^{2}=0.57\end{array}$ & $\begin{array}{c}\text { Upper Limit. } \\
R_{a d j}{ }^{2}=0.54\end{array}$ & $\begin{array}{c}\text { ED50. } \\
R_{a d j}{ }^{2}=0.32\end{array}$ \\
\hline $\mathrm{H}^{2}$ & - & $0.94 \pm 0.28$ & $1.28 \pm 0.30$ & $-0.98 \pm 0.36$ \\
\hline Distance (D) & $-0.74 \pm 0.24$ & - & - & $1.10 \pm 0.23$ \\
\hline $\mathrm{D}^{2}$ & $0.63 \pm 0.23$ & - & - & $-1.14 \pm 0.22$ \\
\hline Climate 1 & - & $-0.85 \pm 0.13$ & $-0.78 \pm 0.14$ & - \\
\hline Climate 2 & $0.26 \pm 0.10$ & $0.20 \pm 0.08$ & - & - \\
\hline Climate 3 & - & - & - & - \\
\hline Climate 4 & $-0.26 \pm 0.08$ & - & $-0.13 \pm 0.06$ & - \\
\hline Soil 1 & - & $0.23 \pm 0.10$ & - & - \\
\hline Soil 2 & - & $-0.12 \pm 0.06$ & $-0.19 \pm 0.06$ & - \\
\hline Soil 3 & $0.28 \pm 0.09$ & - & - & - \\
\hline Soil 4 & $-0.33 \pm 0.12$ & $-0.65 \pm 0.09$ & $-0.60 \pm 0.10$ & - \\
\hline Soil 5 & $0.28 \pm 0.09$ & $0.35 \pm 0.07$ & $0.33 \pm 0.07$ & - \\
\hline Soil 6 & - & - & - & \\
\hline
\end{tabular}

*Note: Standardized regression coefficients are statistically significant for $\mathrm{p}<0.05$

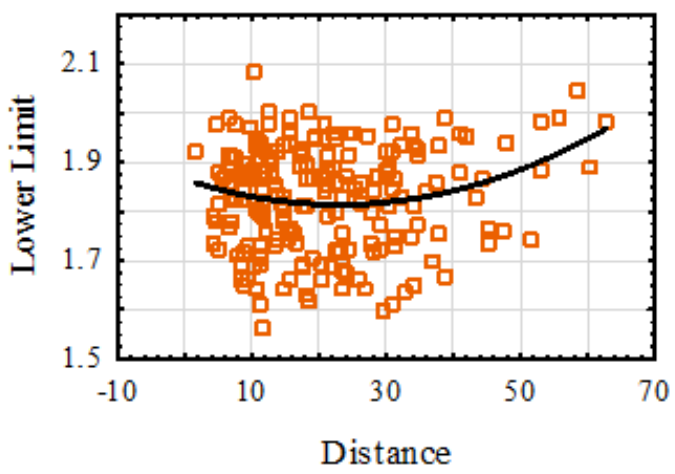

A

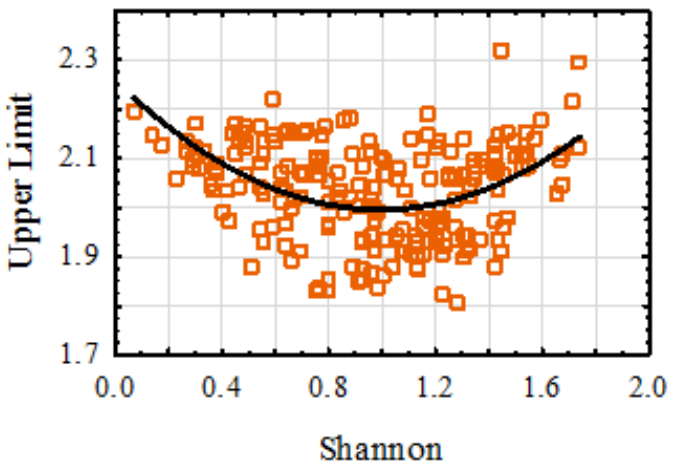

B

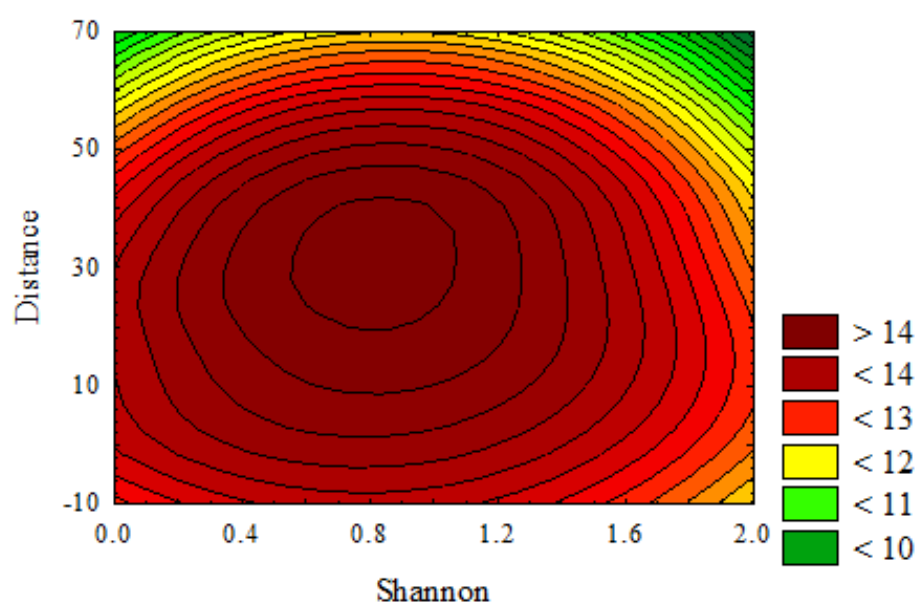

$\mathrm{C}$

Figure 3: The dependence of the minimum level of potato yield on the average distance of the administrative district from the nearest natural protected area (Distance) (A), the maximum level of yield from the landscape diversity (Shannon) (B), and the dependence of ED50 on the landscape diversity and the distance NPA (C) 
Notably, the level of landscape diversity plays an important role in varying potato yields (Table 1). Thus, the growth rate of potato yield is characterized by a nonlinear dependence on the distance to the NPA (Figure 3 , A). The maximum and minimum potato yields are significantly affected by the diversity of landscape cover (Table 1, Figure 3, B). The lowest, highest yield levels and the slope of the trend model variate regularly with the changes both in the landscape-ecological diversity marked by the Shannon index changes and the distance to the nearest NPA. The pattern is non-linear, which indicates the presence of the optimal ratio of diversity in which there is the smallest decrease in crop yield ("largest" lowest yield) and the highest level of maximum yield. Similarly, there is an optimal value of the diversity and density of NPA for the highest slope of the model (the highest rate of yield increasing over time).

It is obvious that crop yield positively correlated with landscape diversity and density of NPA within units with a low level of these indicators. Nevertheless, under conditions of high landscape diversity and density of NPA potato yield decreases due to the predominance of the landscape cover types that are unfavorable for agriculture because of low soil fertility.

The value of the yield parameter ED50 by $32 \%$ is determined solely by landscape diversity (Table 1). The influence of landscape-ecological diversity and distance to natural protected areas on ED50 is shown in Figure 3, C. The symmetrical configuration of the figure indicates an independent influence of the landscape diversity and NPA density at the time of reaching half of potato yield maximum level. The western regions of the study area characterized by the largest values of ED50 (Figure 4).

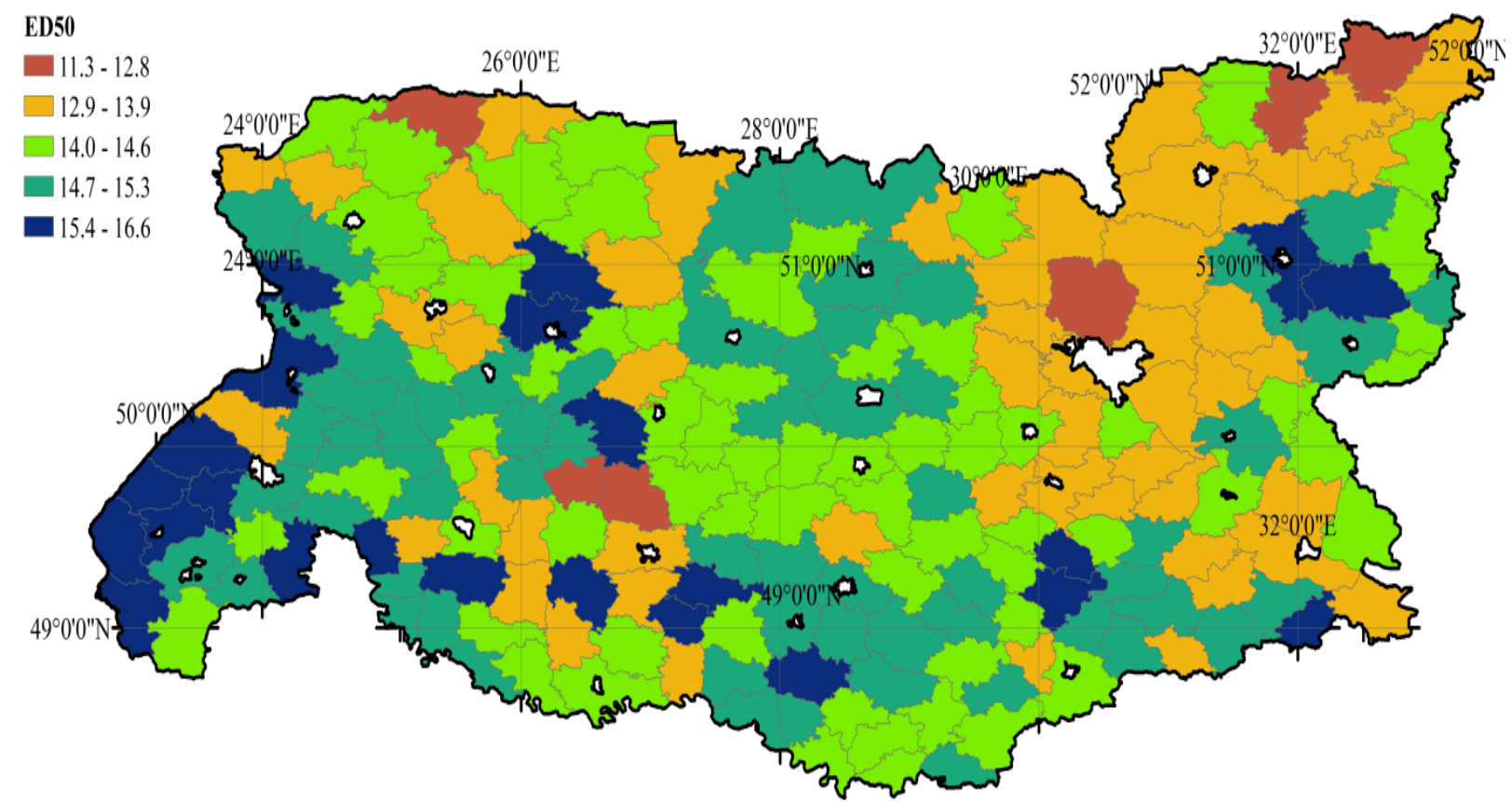

Figure 4: Spatial variation of the inflection time parameter (ED50) of the log-logistic model of potato yield dynamics

The study by Poveda et al. (2012) found a positive effect of landscape diversity on potato yields. Conservation of natural habitats in agricultural landscapes has been shown to be beneficial in providing "ecosystem services" such as reducing pest damage, increasing yields and increasing functional biodiversity (Cardinale et al., 2003; Martin et al., 2016). The simplification of agricultural landscapes through the increase in the cropped areas has caused the loss of habitats for many species that fulfill important ecosystem services such as crop pest regulation and potato yield (Poveda et al., 2012). Even though the yield variation 
caused by the landscape diversity is insignificant, it may be a sufficient condition for the conservation of natural landscape elements within agricultural lands, due to their important ecological role.

The slope of the logarithmic curve, which determines the rate of yield growth is the parameter of the potato yield model that least dependent on agroecological factors $\left(\mathbf{R}_{a d j}{ }^{2}=0.26\right)$. Nevertheless, the slope dependent on the soil principal components $3,4,5$, and most correlates with the soil principal component 4 ( $\mathrm{R}=-0.33$ $\pm 0.12 ; \mathrm{p}<0.05$ ), which is responsible for the content of the silt fraction in the granulometric composition of the soil. That is, the lower the silt content in the soil. the faster the increase of potato yield. Potatoes are known to grow best on non-gleyed grey and sod-podzolic soils of different mechanical compositions (Fiers et al., 2012). Heavy clay soils are unfavorable for potatoes (Johansen et al., 2015). On such soils, especially in wet years, there is a risk of yield loss due to the rapid spread of plant diseases (Liao et al., 2016; Shi et al., 2019; Mugo et al., 2020). Territorial units, where the rate of increase is higher, are in accordance with the predominance of light soils (Figure 1, Figure 5).

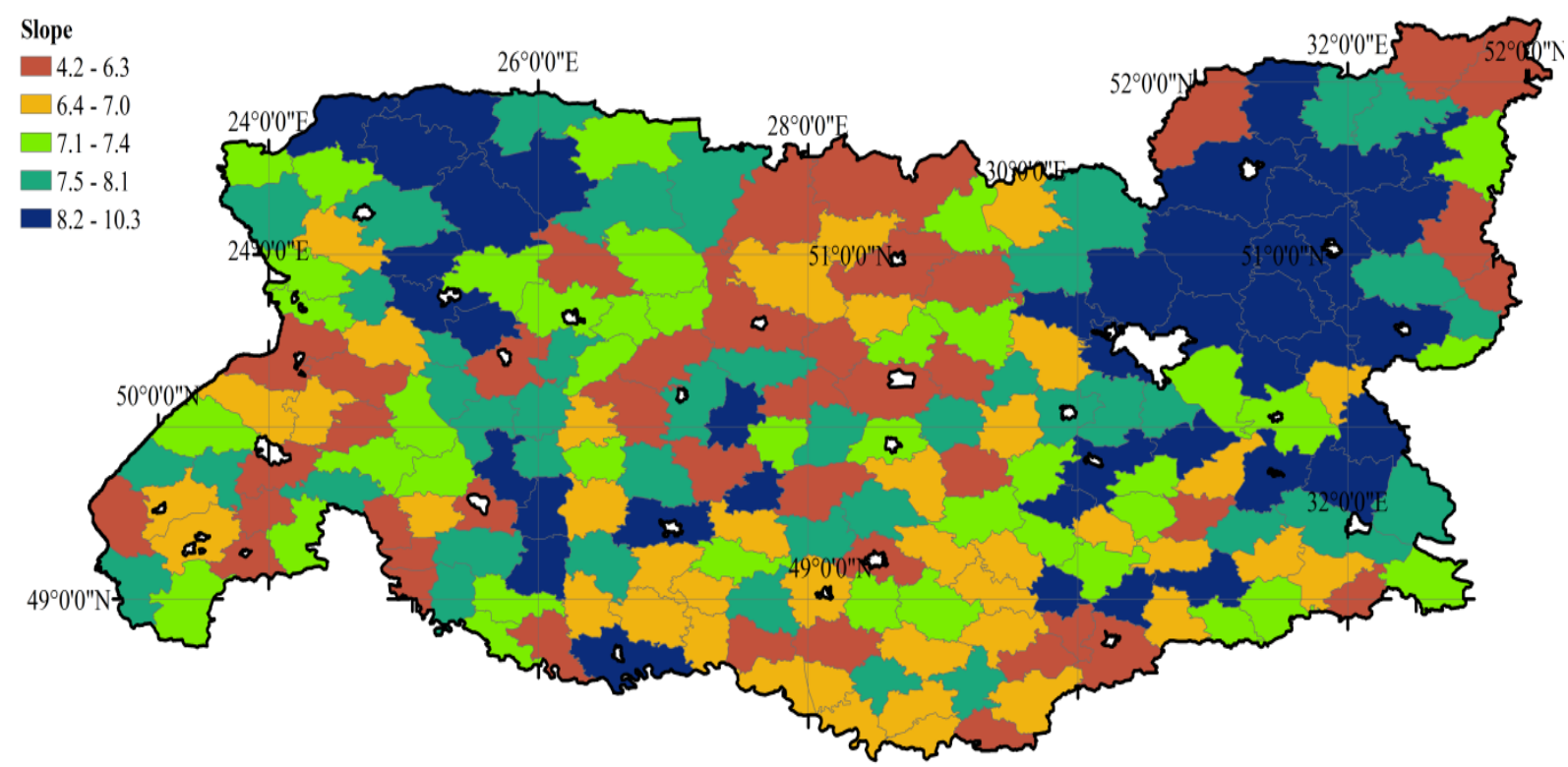

Figure 5: Spatial variation of the Slope parameter of the log-logistic model of potato yield dynamics

So, present study proves the fact that among the most influential factors driving potato yield variability between fields are soil texture components (sand, silt, clay), which in some cases have an even stronger impact on yield than the soil chemical properties (Redulla et al., 2002). The lower and upper limits are the most sensitive potato yield parameters to ecological factors. The environmental factors determine $57 \%$ and $54 \%$ of the spatio-temporal variation of the lower and upper yield limit, respectively (Table 1 ). These potato yield parameters mostly depend on the climatic principal component $1(R=-0.85 \pm 0.13$ and $R=-0.78 \pm$ 0.14 , respectively), which determines the climate continentality. Continentality reflects the most important climatic properties, such as the degree of variability of the annual temperature range. As continentality increases, summer temperatures rise, and winter temperatures fall (Driscoll and Fong, 1992). The soil principal component 4 is also a considerable determinant of lower and upper potato yield limits $(R=-$ $0.65 \pm 0.09$ and $R=-0.60 \pm 0.10$, respectively). The fact that these two parameters depend on the same ecological predictors, determines their similar spatial distribution (Figure 6). 


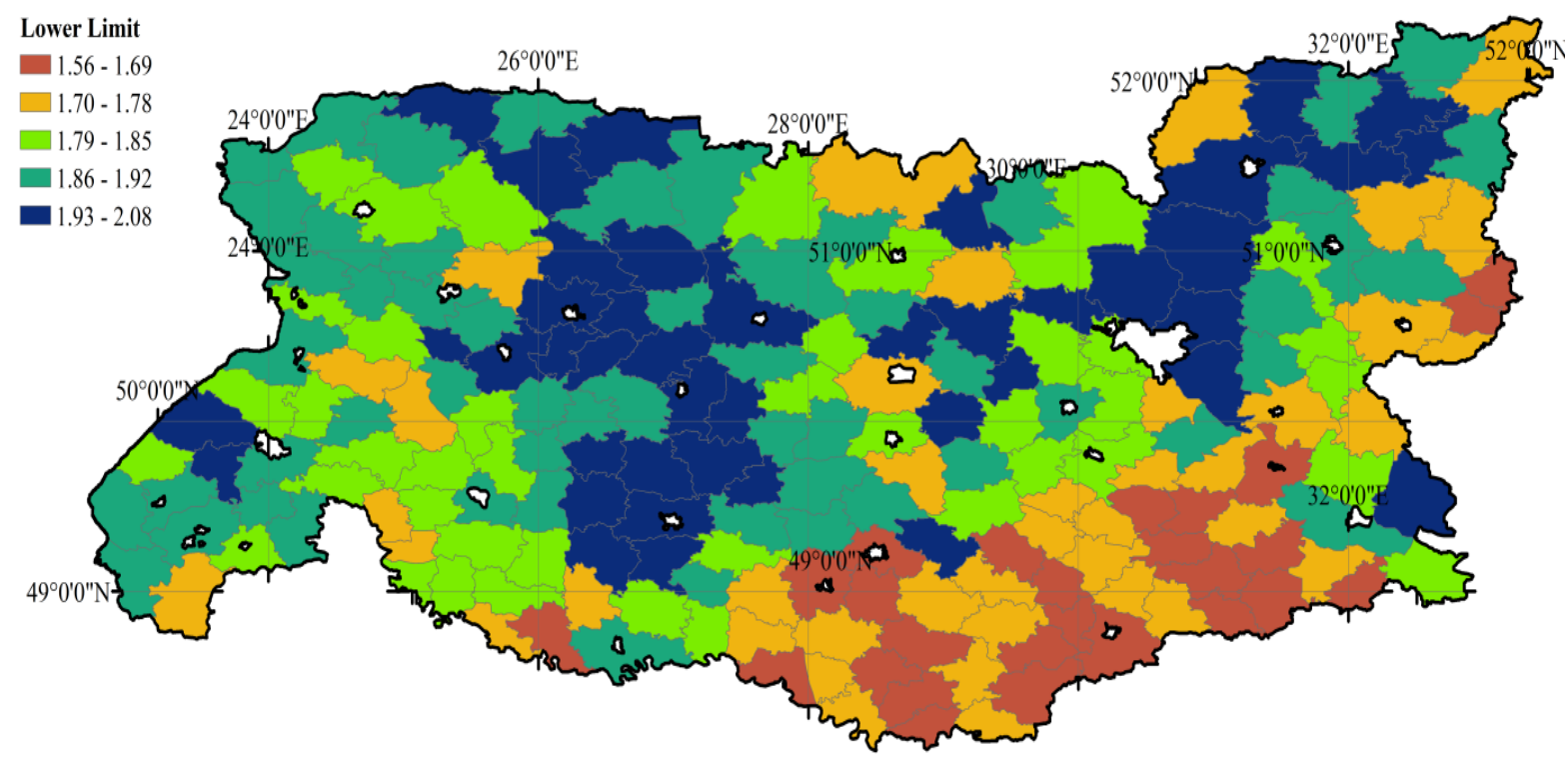

A

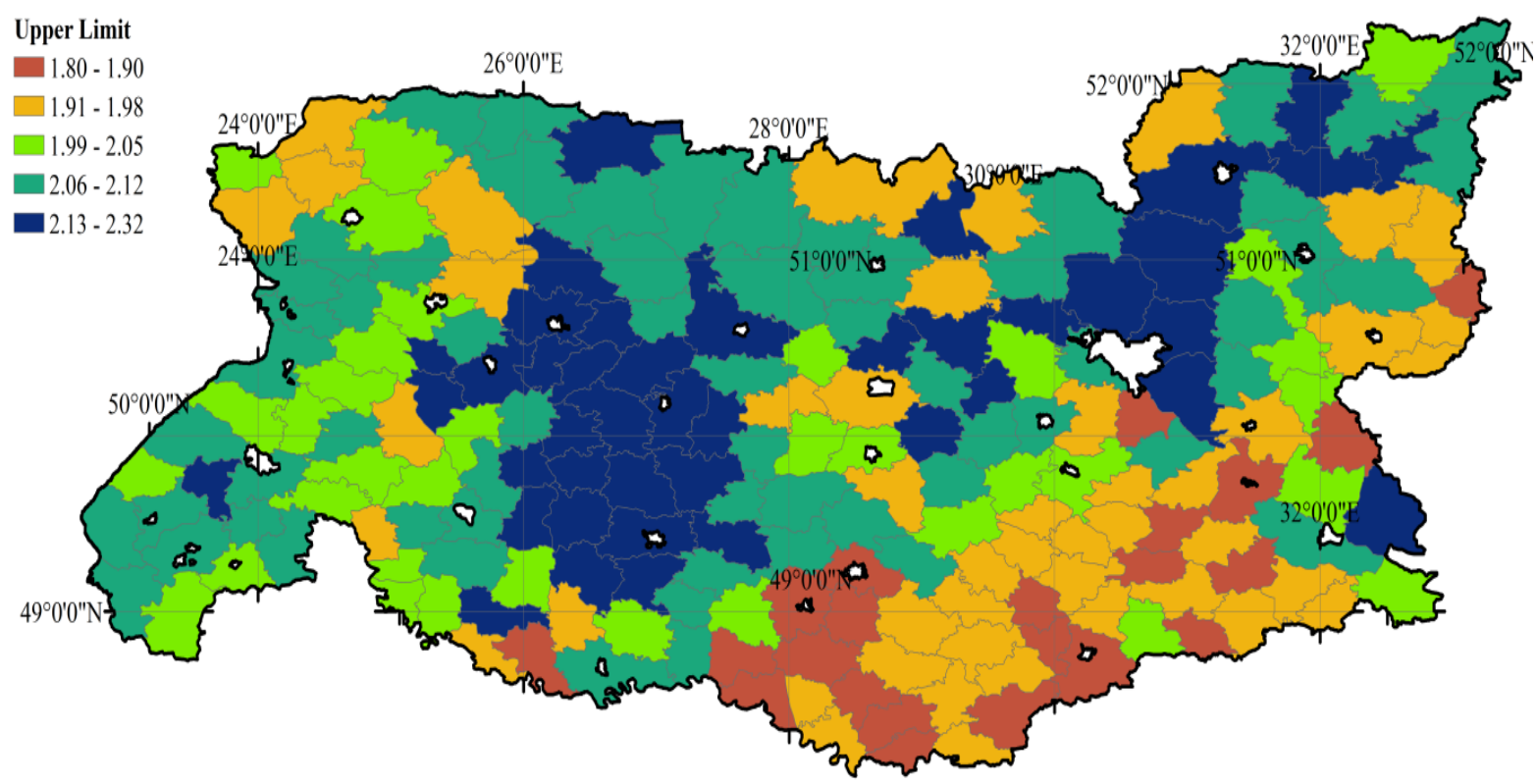

B

Figure 6: Spatial variation of the parameter of the lower limit (A) and upper limit (B) parameters of the loglogistic model of potato yield dynamics

Most of the potato farms in Ukraine are located on the black soils in the forest-steppe zone in central Ukraine, but the best yields are obtained in the Polissia wetlands of the north. The lowest potato yields both in the 1990s and at the current time are observed in the south-eastern regions of the country (Figure 6), which may be connected with the greater climate continentality of this area in particular. Analyses of historical climate data show an obvious trend towards increasing temperatures in Ukraine, and climate models predict further warming. especially regarding winter temperatures (IPCC, 2013). In other words, the climate became more continental in the Polissia zone of Ukraine (Zymaroieva et al., 2021). The possible risks of such a climate change scenario will be the further research to be recommended. 
Grassroots Journal of Natural Resources, Vol.4, No.2 (June 2021), pp.34-47 | ISSN 2581-6853 | CODEN GJNRA9

Doi: https://doi.org/10.33002/nr2581.6853.040203

OPEN OA ACCESS Freely available online

\section{Conclusions}

Potato yield is greatly determined by the diversity of landscape cover. The relationship between yield parameters and landscape-ecological diversity is non-linear, which determines the presence of optimal diversity of natural protected areas for the highest potato yields. Among climatic factors, the continental climate is of the greatest importance for potato yield, and among soil factors, the content of silt in the soil is the most influential factor, which obviously explains the higher potato yields in northern parts of Ukraine.

\section{References}

Abson, D.J., Fraser, E.D.G. and Benton, T.G. (2013). Landscape diversity and the resilience of agricultural returns: A portfolio analysis of land-use patterns and economic returns from lowland agriculture. Agriculture and Food Security, 2(1): 1-15. DOI: https://doi.org/10.1186/2048-7010-2-2.

Cardinale, B.J., Harvey, C.T., Gross, K. and Ives, A.R. (2003). Biodiversity and biocontrol: Emergent impacts of a multi-enemy assemblage on pest suppression and crop yield in an agroecosystem. Ecology Letters, 6(9): 857-865. DOI: https://doi.org/10.1046/j.1461-0248.2003.00508.x.

Chape, S., Harrison, J., Spalding, M. and Lysenko, I. (2005). Measuring the extent and effectiveness of protected areas as an indicator for meeting global biodiversity targets. Philosophical Transactions of the Royal Society B: Biological Sciences, 360(1454): 443-455. DOI: https://doi.org/10.1098/rstb.2004.1592.

Diacono, M., Castrignanò, A., Troccoli, A., De Benedetto, D., Basso, B. and Rubino, P. (2012). Spatial and temporal variability of wheat grain yield and quality in a Mediterranean environment: A multivariate geostatistical approach. Field Crops Research, 131: 49-62. DOI: https://doi.org/10.1016/j.fcr.2012.03.004.

Driscoll, D.M. and Fong, J.M.Y. (1992). Continentality: A basic climatic parameter re-examined. International Journal of Climatology, 12(2): 185-192. DOI: https://doi.org/10.1002/joc.3370120207.

Dušek, R. and Popelková, R. (2017). Theoretical view of the Shannon index in the evaluation of landscape diversity. Acta Universitatis Carolinae. Geographica. Univerzita Karlova, 47(2): 5-13. DOI: https://doi.org/10.14712/23361980.2015.12.

FAO (2019). FAOSTAT, FAO Statistical Databases. Available online at: http://www.fao.org/faostat/en/\#home [Accessed on 13 March 2021]

Fedonyuk, T.P., Galushchenko, O.M., Melnichuk, T.V., Zhukov, O.V., Vishnevskiy, D.O., Zymaroieva, A.A. and Hurelia, V.V. (2020). Prospects and main aspects of the GIS-technologies application for monitoring of biodiversity (on the example of the Chornobyl Radiation-Ecological Biosphere Reserve). Kosmična nauka i tehnologiâ, 26(6): 75-93. DOI: https://doi.org/10.15407/knit2020.06.075.

Feller, C., Blanchart, E., Bernoux, M., Lal, R. and Manlay, R. (2012). Soil fertility concepts over the past two centuries: The importance attributed to soil organic matter in developed and developing countries. Archives of Agronomy and Soil Science, 58(SUPPL.): 3S-S21. DOI: https://doi.org/10.1080/03650340.2012.693598.

Fiers, M., Edel-Hermann, V., Chatot, C., Le Hingrat, Y., Alabouvette, C. and Steinberg, C. (2012). Potato soil-borne diseases. A review. Agronomy for Sustainable Development, 32(1): 93-132. DOI: https://doi.org/10.1007/s13593-011-0035-zï.

Fick, S.E. and Hijmans, R.J. (2017). Worldclim 2: New 1-km spatial resolution climate surfaces for global land areas. International Journal of Climatology, 37: 4302-4315. DOI: https://doi.org/10.1002/joc.5086.

Fritz, S., See, L., McCallum, I., You, L., Bun, A., Moltchanova, E., Dürauer, M., Albrecht, F., Schill, C., Perger, C., Havlík, P., Mosnier, A., Thornton, P., Wood-Sichra, U., Herrero, M., Becker-Reshef, I., Justice, C., Hansen, M., Gong, P. and Obersteiner, M. (2015). Mapping global cropland and field size. Global Change Biology, 21(5): 1980-1992. DOI: https://doi.org/10.1111/gcb.12838.

Hamkalo, Z. (2005). Fertilizer use by crop in Ukraine. Rome: FAO. DOI: https://doi.org/10.13140/2.1.2230.2404. 
Grassroots Journal of Natural Resources, Vol.4, No.2 (June 2021), pp.34-47 | ISSN 2581-6853 | CODEN GJNRA9

Doi: https://doi.org/10.33002/nr2581.6853.040203

OPEN OA ACCESS Freely available online

Haverkort, A.J. and Struik, P.C. (2015). Yield levels of potato crops: Recent achievements and future prospects. Field Crops Research, 182: 76-85. DOI: https://doi.org/10.1016/j.fcr.2015.06.002.

Hengl, T., Mendes de Jesus, J., Heuvelink, G.B.M., Ruiperez Gonzalez, M., Kilibarda, M. and Blagotić, A. (2017). SoilGrids250m: Global gridded soil information based on machine learning. PLoS ONE, 12(2): e0169748. DOI: https://doi.org/10.1371/journal.pone.0169748.

Hooper, D.U., Chapin, F.S., Ewel, J.J., Hector, A., Inchausti, P., Lavorel, S., Lawton, J.H., Lodge, D.M., Loreau, M., Naeem, S., Schmid, B., Setälä, H., Symstad, A.J., Vandermeer, J. and Wardle, D.A. (2005). Effects of biodiversity on ecosystem functioning: a consensus of current knowledge. Ecological Monographs, 75: 3-35. DOI: https://doi.org/10.1890/04-0922.

IPCC. (2013). Climate Change 2013: The Physical Science Basis. Contribution of Working Group I to the Fifth Assessment Report of the Intergovernmental Panel on Climate Change. Cambridge, United Kingdom and New York, NY, USA: Cambridge University Press.

Jennings, S.A., Koehler, A.K., Nicklin, K.J., Deva, C., Sait, S. M. and Challinor, A.J. (2020). Global Potato Yields Increase Under Climate Change With Adaptation and $\mathrm{CO}^{2}$ Fertilisation. Frontiers in Sustainable Food Systems, 4: 519324. DOI: https://doi.org/10.3389/fsufs.2020.519324.

Johansen, T.J., Thomsen, M.G., Løes, A.K. and Riley, H. (2015). Root development in potato and carrot crops - influences of soil compaction. Acta Agriculturae Scandinavica Section B: Soil and Plant Science. London: Taylor and Francis Ltd., pp.182-192. DOI: https://doi.org/10.1080/09064710.2014.977942.

Koshelev, O.I., Koshelev, V.O., Fedushko, M.P. and Zhukov, O.V. (2020). Time turnover of species in bird communities: the role of landscape diversity and climate change. Biosystems Diversity, 28(4): 433444. DOI: https://doi.org/10.15421/012056.

Kunah, O.M., Pakhomov, O.Y., Zymaroieva, A.A., Demchuk, N.I., Skupskyi, R.M., Bezuhla, L.S. and Vladyka, Y.P. (2018). Agroeconomic and agroecological aspects of spatial variation of rye (Secale cereale) yields within Polesia and the Forest-Steppe zone of Ukraine: The usage of geographically weighted principal components analysis. Biosystems Diversity, 26(4): 276-285. DOI: https://doi.org/10.15421/011842.

Lal, R. (2020). Soil organic matter content and crop yield. Journal of Soil and Water Conservation, 75(2): 27-32. DOI: https://doi.org/10.2489/JSWC.75.2.27A.

Liao, X., Su, Z., Liu, G., Zotarelli, L., Cui, Y. and Snodgrass, C. (2016). Impact of soil moisture and temperature on potato production using seepage and center pivot irrigation. Agricultural Water Management, 165: 230-236. DOI: https://doi.org/10.1016/j.agwat.2015.10.023.

Majka, D., Jenness, J. and Beier, P. (2007). CorridorDesigner: ArcGIS tools for designing and evaluating corridors. Available online at http://corridordesign.org/ [Accessed on March 10, 2015].

Martin, E.A., Seo, B., Park, C.R., Reineking, B. and Steffan-Dewenter, I. (2016). Scale-dependent effects of landscape composition and configuration on natural enemy diversity, crop herbivory, and yields. Ecological Applications, 26(2): 448-462. DOI: https://doi.org/10.1890/15-0856.

McGarigal, K., Cushman, S.A., Neel, M.C. and Ene, E. (2012). Fragstats Landscape Metrics, 90(2007): 699-710. DOI: https://doi.org/10.1890/08-0576.1.

McGarigal, K.S., Cushman, S., Neel, M. and Ene, E. (2002). FRAGSTATS: Spatial pattern analysis program for categorical maps. Computer software program produced by the authors at the University of Massachusetts, Amherst. Available online at: www.umass.edu/landeco/research/fragstats/fragstats.html. [Accessed on 10 March 2021]

Mugo, J.N., Karanja, N.N., Gachene, C.K., Dittert, K., Nyawade, S.O. and Schulte-Geldermann, E. (2020). Assessment of soil fertility and potato crop nutrient status in central and eastern highlands of Kenya. Scientific Reports, 10(1): 1-11. DOI: https://doi.org/10.1038/s41598-020-64036-x.

Osman, D., Ozgur, A. and Ozlem, I. (2014). A Methodology to Implement Box-Cox Transformation When No Covariate is Available. Communications in Statistics- Simulation and Computation, 43: 1740 1759. DOI: https://doi.org/10.1080/03610918.2012.744042.

Ottlé, C., Lescure, J., Maignan, F., Poulter, B., Wang, T. and Delbart, N. (2013). Use of various remote sensing land cover products for plant functional type mapping over Siberia. Earth System Science Data, 5(2): 331-348. DOI: https://doi.org/10.5194/essd-5-331-2013. 
Pereira, A.B., Villa Nova, N.A., Ramos, V.J. and Pereira, A.R. (2008). Potato potential yield based on climatic elements and cultivar characteristics. Bragantia, 67(2): 327-334. DOI: https://doi.org/10.1590/S0006-87052008000200008.

Pérez-Hoyos, A., Rembold, F., Kerdiles, H. and Gallego, J. (2017). Comparison of Global Land Cover Datasets for Cropland Monitoring. Remote Sensing, 9(11): 1118. DOI: https://doi.org/10.3390/rs9111118.

Picasso, V.D, Brummer, E.C, Liebman, M, Dixon, P. and Wilsey, B.J. (2008). Crop species diversity affects productivity and weed suppression in perennial polycultures under two management strategies. Crop Science, 48: 331-342. DOI: https://doi.org/10.2135/cropsci2007.04.0225

Poveda, K., Martinez, E., Kersch-Becker, M., Bonilla, M. and Tscharntke, T. (2012). Landscape simplification and altitude affect biodiversity, herbivory and Andean potato yield. Journal of Applied Ecology, 49: 513-522. DOI: https://doi.org/10.1111/J.1365-2664.2012.02120.X.

Quiroz, R., Ramírez, D.A., Kroschel, J., Andrade-Piedra, J., Barreda, C., Condori, B., Mares, V., Monneveux, P. and Perez, W. (2018). Impact of climate change on the potato crop and biodiversity in its center of origin. Open Agriculture, 3(1): 273-283. DOI: https://doi.org/10.1515/opag-20180029.

$\mathrm{R}$ Core Team (2020). A Language and Environment for Statistical Computing. R: A language and environment for statistical computing. $R$ Foundation for Statistical Computing, Vienna, Austria. Available online at: https://www.R-project.org/ [Accessed on 22 April 2021]

Ray, D.K., Gerber, J.S., Macdonald, G. K. and West, P.C. (2015). Climate variation explains a third of global crop yield variability. Nature Communications, 6: 5989. DOI: https://doi.org/10.1038/ncomms6989.

Redulla, C.A., Davenport, J.R., Evans, R.G., Hattendorf, M.J., Alva, A.K. and Boydston, R.A. (2002). Relating potato yield and quality to field scale variability in soil characteristics. American Journal of Potato Research, 79(5): 317-323. DOI: https://doi.org/10.1007/BF02870168.

Ritz, C., Baty, F., Streibig, J. C. and Gerhard, D. (2015). Dose-Response Analysis Using R. PLOS ONE, 10(12): e0146021. DOI: https://doi.org/10.1371/journal.pone.0146021.

Schmidhuber, J. and Tubiello, F.N. (2007). Global food security under climate change. Proceedings of the National Academy of Sciences of the United States of America: 19703-19708. DOI: https://doi.org10.1073/pnas.0701976104.

Shi, W., Li, M., Wei, G., Tian, R., Li, C., Wang, B., Lin, R., Shi, C., Chi, X., Zhou, B. and Gao, Z. (2019). The occurrence of potato common scab correlates with the community composition and function of the geocaulosphere soil microbiome. Microbiome, 7(1): 1-18. DOI: https://doi.org/10.1186/s40168019-0629-2.

Stol, W., de Koning, G. H. J., Kooman, P. L. and van Keulen, H. (1991). Agro-ecological characterization for potato production: a simulation study at the request of the International Potato Center (CIP), Lima, Peru (Report / Centre for Agrobiological Research; No. 155): CABO-DLO. Available online at: https://edepot.wur.nl/331148 [Accessed on 12 Amy 2021]

Tsendbazar, N.E., de Bruin, S., Fritz, S. and Herold, M. (2015). Spatial accuracy assessment and integration of global land cover datasets. Remote Sensing, 7(12): 15804-15821. DOI: https://doi.org/10.3390/rs71215804.

Wang, N., Xing, Y. and Wang, X. (2019). Exploring Options for Improving Potato Productivity through Reducing Crop Yield Gap in Loess Plateau of China Based on Grey Correlation Analysis. Sustainability, 11(20): 1-14. DOI: https://doi.org/10.1016/j.scitotenv.2016.08.195.

Zhao, J., Zhang, Y., Qian, Y., Pan, Z., Zhu, Y., Zhang, Y., Guo, J. and Xu, L. (2016). Coincidence of variation in potato yield and climate in northern China. Science of the Total Environment, 573: 965973. DOI: https://doi.org/10.1016/j.scitotenv.2016.08.195.

Zhukov, O.V., Pisarenko, P.V., Kunah, O.M. and Dichenko, O.J. (2015). Role of landscape diversity in dynamics of abundance of sugar beet pest population in Poltava region. Visnyk of Dnipropetrovsk University: Biology (Ecology), 23(1): 21-27 (in Ukranian). DOI: https://doi.org/10.15421/011504. 
Zhukov, A.V., Sirovatko, V.O. and Ponomarenko, N.O. (2017). Spatial dynamic of the agriculture fields towards their shape and size. Ukrainian Journal of Ecology, 7(3): 14-31. DOI: https://doi.org/10.15421/2017_45.

Zhukov, O.V., Pelina, T. O., Demchuk, O.M., Demchuk, N.I. and Koberniuk, S.O. (2018). Agroecological and agroeconomic aspects of the grain and grain legumes (pulses) yield dynamic within the Dnipropetrovsk region (period 1966-2016). Biosystems Diversity, 26(2): 170-176. DOI: https://doi.org/10.15421/011826.

Zymaroieva, A. and Zhukov, O. (2020). Analyzing cereal and grain legumes (pulses) yields patterns in the forest and forest-steppe zones of Ukraine using geographically weighted principal components analysis. Acta Agriculturae Slovenica, 116(2): 287-297. DOI: https://doi.org/10.14720/aas.2020.116.2.873.

Zymaroieva, A., Zhukov, O. and Romanchuck, L. (2020). The spatial patterns of long-term temporal trends in yields of soybean (Glycine max (1.) merril) in the central european mixed forests (polissya) and East European forest steppe ecoregions within Ukraine. Journal of Central European Agriculture, 21(2): 320-332. DOI: https://doi.org/10.5513/JCEA01/21.2.2402.

Zymaroieva, A., Zhukov, O., Fedoniuk, T., Pinkina, T. and Vlasiuk, V. (2021). Edaphoclimatic factors determining sunflower yields spatiotemporal dynamics in northern Ukraine. $O C L, 28: 26$. DOI: https://doi.org/10.1051/ocl/2021013. 


\section{Authors' Declarations and Essential Ethical Compliances}

Authors' Contributions (in accordance with ICMJE criteria for authorship)
\begin{tabular}{|l|l|l|l|l|l|}
\hline Contribution & Author 1 & Author 2 & Author 3 & Author 4 & Author 5 \\
\hline $\begin{array}{l}\text { Conceived and designed the research or } \\
\text { analysis }\end{array}$ & Yes & Yes & Yes & Yes & Yes \\
\hline Collected the data & Yes & No & No & No & No \\
\hline $\begin{array}{l}\text { Contributed to data analysis \& } \\
\text { interpretation }\end{array}$ & Yes & Yes & Yes & Yes & Yes \\
\hline Wrote the article/paper & Yes & No & No & No & No \\
\hline Critical revision of the article/paper & Yes & Yes & Yes & Yes & Yes \\
\hline Editing of the article/paper & Yes & No & Yes & No & Yes \\
\hline Supervision & Yes & Yes & No & No & Yes \\
\hline Project Administration & No & Yes & No & No & No \\
\hline Funding Acquisition & No & No & No & No & No \\
\hline Overall Contribution Proportion $(\%)$ & 50 & 20 & 10 & 10 & 10 \\
\hline
\end{tabular}

\section{Funding}

No funding was available for the research conducted for and writing of this paper.

Research involving human bodies (Helsinki Declaration)

Has this research used human subjects for experimentation? No

Research involving animals (ARRIVE Checklist)

Has this research involved animal subjects for experimentation? No

\section{Research involving Plants}

During the research, the authors followed the principles of the Convention on Biological Diversity and the Convention on the Trade in Endangered Species of Wild Fauna and Flora.

Research on Indigenous Peoples and/or Traditional Knowledge

Has this research involved Indigenous Peoples as participants or respondents? No

(Optional) PRISMA (Preferred Reporting Items for Systematic Reviews and Meta-Analyses)

Have authors complied with PRISMA standards? Yes

\section{Competing Interests/Conflict of Interest}

Authors have no competing financial, professional, or personal interests from other parties or in publishing this manuscript.

\section{Rights and Permissions}

Open Access. This article is licensed under a Creative Commons Attribution 4.0 International License, which permits use, sharing, adaptation, distribution and reproduction in any medium or format, as long as you give appropriate credit to the original author(s) and the source, provide a link to the Creative Commons license, and indicate if changes were made. The images or other third-party material in this article are included in the article's Creative Commons license, unless indicated otherwise in a credit line to the material. If material is not included in the article's Creative Commons license and your intended use is not permitted by statutory regulation or exceeds the permitted use, you will need to obtain permission directly from the copyright holder. To view a copy of this license, visit http://creativecommons.org/licenses/by/4.0/. 